\title{
SOLICITORS' WORK AND EXVIRONMEXT.'
}

THE Conmittee of the Cambridge Cuiversity Law Society, 1 when they honoured me with the invitation to address the society, had doubtless the expectation that a solicitor who had been in practice for between forty and fifty years might from his experience be able to explain the work and environment of the profession in a way which might be useful to those members of the society who, having deternined to follow the legal profession, had not yet decided to which branch of that profession they should devote their lives. I will endeavour to fulfil that expectation. I will draw for you the picture of a solicitor's professional life and work and surroundings with such accurary as my powers and the time at my disposal permit, not concenling its blemishes or exaggerating its merits. I hope that I shall be able to make you see the picture right. If so, you will, when I have finished, agree with me that though the highest honours and emoluments of the legal profession are not at present open to solicitors, yet theirs is a calling which renders to the community an important-indeed, an essential-service, and one to which a man of ability, and still more of character, may devote himself with confidence as affording ample scope for his energy and ambition. I claim for the protession that, properly practised, it can and does do nothing but good. Unless I were prepared to make that claim after forty-seven years' experience in the profession, I should not be here. I resent the representations by popular novelists and dramatists of the solicitor as at costs-pursuing pettifogger, if nothing worse. Dickens heads the tribe of libellers with representations which, even as caricatures, are grossly overdrawn. In his celebrated preface and first. chapter of "Bleak House" he discloses his motive, which was the laudable one of the correction of abuses of legal procedure. At the time he was writing (the middle of the nineteenth century) those abuses no doubt prevailed. But I hope I need not assure my present audience that Messrs. Kenge and Carboy, Mr. Tulkingherne, Messrs. Spenlow and Jorkins, Messrs. Dodson and Fogg, and all the rest, however entertaining in works of fiction,

1 This paper was read to the University Law Society on December 2, 1920, by Mr. S. Garrett, ex-President of the Law Society, London. 
are nothing more or less than fanciful romance. They are true to nothing in real life that $I$ have ever seen. They are no more faithful representations of solicitors than " the young man of the name of Guppy" is a faithful representation of solicitors' clerks. In his preface to "Bleak House" Dirkens says that he has purposely dwelt on the romantic side of familiar things. In the chapter entitled "Attorney and Client" he writes:-

"The one great principle of the English law is to make business for itself. There is no other principle distinctly, certainly and consistently maintained through all its narrow turnings. Viewed by this light it hecomes a coherent scheme and not the monstrous maze the laity is apt to think it. Let them but once clearly perceive that the grand principle is to make business for itself at their expense and surely they will cease to grumble."

The romantic side of familiar things: If he had said that his theme was the familiar side of popular ignorance and prejudice he would have been nearer the truth. This ignorance and prejudice he did his best to inflame, not without success. If a tithe of what he wrote on the subject were true no man of honour could follow the profession of the law or encourage younger men to do so. It is certainly a misfortune for the profession that a man of genius, whose writings have dominated a section of the reading public for three generations, should have so persistently held up the profession to odium and ridicule. One derives some consolation, however, from the reflection that Dickens brought up one of his sons to the law, and that that son has attained a prominent and honourable position in the profession which his father habitually calumniated.

Therefore, if any of you are admirers of Dickens (as I am), do not be discouraged by the picture of the law and of lawyers which he drans. Reflect that it is only the romantic-that is, the fanciful-side of familiar things. I hope that the account which I shall now give you of my omn branch of the profession will satisfy you that Dickens's picture is fanciful to the point of falsity.

The first thing which a man should understand before he enters a profession is its organization. In the law everyone is familiar with the fact that there are in this country two branches, as they are called, of the profession-the Bar and Solicitors. It is convenient to call them "branches" of the profession, and I shall myself use the expression, but the expression, though convenient, is inaccurate. The word "branch" imports a common stem, or, at any rate, a common root, from 
which all the branches spring. In this sense barristers and solicitors are not branches of one profession. They are two distinct professions, working in water-tight compartments, distinct in their origin, in their history, in their education, and in their work. Whether it is desirable in the public interest that this complete and radical division should continue, is a question which has often been discussed, and which will be more discussed in the future. But $I$ am dealing to-night more with what is than with what ought to be, and $I$ shall not enter upon a discussion of this subject further than to say that in my view, while the work of a solicitor is not only different from that of the barrister but is in its nature in some respects inconsistent with the temperament and character of the effective advocate, yet both branches would benefit by a greater community in education and intercourse than prevails at present. In education it seems an absurd waste of power that there should exist two establishments for legal education, one in Chancery Lane for the education of students who propose to become solicitors, and another about one hundred yards distant, in Lincoln's Inn, for the education of students for the Bar, where the same subjects are taught by teachers of the same class to students of the same class. Surely great economy of time and labour and money would be effected by an amalgamation of these two educational establishments. Further, it seems to me that nothing but good would result from the two sets of students rubbing shoulders with each other in the class-room and the examination-hall. In their subsequent professional career the two will have dealings with each other, and the difficulties which, human nature being what it is, will from time to time arise would be treated on both sides with more sympathy and consideration if the parties had received their legal education together in the same class-room.

The subject of the legal education of solicitors brings me to the consideration of the position and functions of the Law Society. The Society bulks large in the professional life of all solicitors, though all solicitors are not members of it. Membership is entirely voluntary at present. There are about 14,000 practising solicitors in England and Wales. About 9,000 of them are members of the Law Society. But in addition to The Law Society there are provincial law societies in all the principal centres of population, such as Liverpool, Manchester, Birmingham, Newcastle, Bristol, Yorkshire, etc. These provincial societies are united to each other in an Association of Provincial Law Societies, and both the association and the separate societies are in close touch with the central society in London. Thus the 
central society in conjunction with the provincial societies does in fact represent in substance the whole profession.

Great ignorance prevails among the laity as to the objects and powers of the Law Society, and a few words on the subject may be useful. That Society was founded in the year 1825 by members of an older society called "The Society of Gentlemen Practisers in the Courts of Law and Equity." The object of the earlier society was to take into consideration " matters relating to the benefit of suitors and the honour of the profession." The society was founded in 1739. About that time (the exact date is obscure) the Inns of Court, as we now know them, succeeded in excluding from membership all solicitors, who thereafter betook themselves to the so-called Inns of Chancery (New Inn, Clement's Inn, Sergeants' Inn, Thavie's Inn, and Barnard's Inn and others). By this means was established, not a division of functions, which had existed from a much earlier period, but a division of education and discipline which was not part of the original system, and which, in my opinion, as indicated above, might now well be abrogated in large measure with advantage to both branches of the profession. There is a tradition that each Inn of Chancery was affiliated to one of the Inns of Court, and that tradition has been recognized as lately as 1901, when a large sum of money arising from the sale of New Inn was, by order of Court, divided between the Law Society and the Inns of Court for the promotion of the professional education of solicitors and barristers respectively.

The Inns of Chancery soon became mere social and dining clubs, and ceased to fulfil the useful purposes for which they were designed. Then it was that the Society of Gentlemen Practisers, above referred to, was formed. For nearly a century solicitors were entirely dependent upon that society for the protection of their honour and just interests. But there is no record of its having undertaken any educational functions, and in that respect it failed to make good the default of the Inns of Chancery. The Law Society was accordingly formed not only to carry on the useful work of the Society of Gentlemen Practisers but also to re-establish and carry on the educational work of the Inns of Chancery, which had been allowed to lapse. Having been formed as an unincorporated body in 1825, it was incorporated by Royal Charter in 1831, and the charter was reaffirmed in 1845 . The charter stated that the general purposes of the Society were "to promote professional improvement and facilitate the acquisition of legal knowledge."

The Society first made its mark as a public body of importance 
in the year 1843, when the Solicitors Act, 1843, was passed, which is still law and which consolidates and amends previous Acts and appoints the Law Society as registrar of solicitors. Hence it comes that the first thing which an articled clerk dors is to register his articles of clerkship with the Law Society. So commences his connection with the Soriety, which continues throughout his career to dominate and control and, if necessary, to correct his professional actions.

The functions of the Society are both private and pullic. In its private capacity it provides for its members a hall and public rooms, a first-class legal library, a restaurant, and the usual amenities of a club. It is also a very powerful trade union. 13y its own members and by the mombers of provincial law sorieties associated with it, it can exert great influence on lecrislation in any matter affecting the professional interests of solicitors. That influence, it can be fairly chimed, has been used for the pulblic good. Many of the law reforms of recent years hatre oripinated with the Law Society, such, for instance, as the Settled Land Acts. At the present moment it is working hatrd in assisting the Government to inprove and to pass the Law of Proporty Bill now before Parliament, which is founded, except on me very controversial point, viz, compulsory registration of title, on principles which have long been advocated by the Soricty.

I claim for the Society that it takes no narrow view of the professional interests of its nembers. It is governed by a Council of forty of the leading men in the profession elerted by popular vote of the members. The coum il is fully impresseil with the truth that where professional interest and the publir. interest conflict the former must yield, and it is ly the recognition of that fact that the Soriety maintains its just infucnce both with the public and with the professim.

The public functions of the Soriety have heen vastly extended since 1843. It is now not only the registrar of solicitors, but by statutory authority it eximines them and, if necessary, disciplines them. It has from its earliest days edurated them by providing classes and lectures for students, and in the rear 1903 a Sohool of Law was establisleed by the Sorcioty, with at distinguished jurist, Mr. Elward Jenks, as principal, in which all articled clerks in London ran, if they so please, rereive a complete legal education at very moderate cost, and those in the country can be very substantially assisted in their colucation not only by lectures and classes provided by the provincial law societies with the help of money grants marle to them by the central society, but also by correspondence with the traching 
stati of the Soriety's school. The scheme is controlled by a committee appointed by the council, consisting of a majority of representatives of that body and of representatives of the provincial sorieties and of two nominees of the students' soricties.

This is the scheme of legal education which it has been suggested should be amalgamated with the Council of Legal Education, which controls the education of Bar students. Whether that amalgamation takes place or not, the Law Society will, of course, retain rontrol of its own students, and will remain the great legal educator of the country. I have not the exact numbers, but $I$ should expect to find that the students edurated by the Law Society outnumber those educated by the Council of Legal Fiducation by three or four to one.

An amalgamation such as suggested between the Council of Legal Education and the Law Society's School of Law would, as I hope and expect, lie the first step towards the estallishment of a national or even an imperial srhool of law, the want of which is a standing reproach. An amalgamated body representing the educational authorities of both branches of the profession would approach the Government and Parliament with proposal* for the establishment of a national or imperial school with much greater driving force behind it than would be at the disposal of the separate existing bodies. But I must not pursue this theme, which rould lead me away from the proper subject of this address, though I could not resist the temptation of saying these few words on the subjert to my present audience. to whom the matter cannot fail to be of great interest.

Having registered his articles with the Law Society, the articled clerk, if he is wise, will enter himself to attend some of the classes and lectures under the Society's educational scheme. If he is graduated in law at this or another university. he is excused from the examination in elementary law known as the intermediate examination, but he has to pass the final examination at the end of his articles as a condition of heingr admitted on the Roll of Solicitors. The examination system of the Law Society has been critirised lately by a distinguisherl member of the Society, and I am not here to say that it is perfect. I happen at the moment to be chairman of the committee of the Council which controls the examinations. In my opinion the examinations at present afford too much scope for that archenemy of all examiners-the crammer. I hope it will be possible to do something to defeat that gentleman and to indure students. instead of resorting to him, to attend the classes and lectures 
provided by the Society, which afford a far sounder legal education.

Next, perhaps the most important public function performed by the Society is that of discipline. Every student will hope not to come under the Society's disciplinary lash himself, but he will soon learn in the course of his professional career that among 14,000 practitioners there are some for whom that same lash is a very useful and, indeed, necessary instrument. For thirty-two years past, under an Act passed in 1888, all complaints against solicitors have been heard before a committee of the Council appointed by the Master of the Rolls, but the committee had only power to report to the Court the facts and their view of the conduct of the solicitor. The Court alone had power to pronounce sentence upon the facts so found and to punish the solicitor by suspension from practice, or by striking him off the Roll. By an Act passed in 1919, however, the Law Society has power, through its committee, not merely to enquire into the facts but to act upon their finding by suspending the solicitor, or striking him off the Roll, subject to an appeal to the Court. The profession, therefore, now has the power which every other profession has of cleansing its ranks of unworthy members and punishing those who are guilty of miseonduct not sufficiently heinous to deserve permanent expulsion from the ranks of the profession. Nothing less was due to the dignity of the profession.

I wonder what Dickens would have said to this. Most of the solicitors depicted in his novels would in these days have found themselves before the Discipline Committee of the Law Society.

Besides the functions I have mentioned, the Law Society performs a number of other services to the profession. The Council, through a committee, frequently acts as mediator in differences which arise in the course of practice between solicitors on questions of costs and otherwise and as adviser to members on such questions. Another committee deals with questions of legal procedure, and is constantly in communication with the Lord Chancellor with a view to simplifying and improving the procedure of the High Court. Another committee does the same work with reference to the County Courts. Another committee watches the proceedings of Parliament, and takes action when any question of interest to the profession arises in Parliament.

It will be seen, therefore, that the activities of the Society are very various and cover a large field. From the time when a man as an articled clerk registers his articles with the Society to the day when he retires from the profession with, it is to be boped, 
an adequate competency and applies to have his name taken off the Roll of Solicitors the Law Society is always with him. It educates him, examines him, advises him, admonishes him and, if necessary, disciplines him, and is constantly watching and protecting his interests. I think it may be fairly claimed that the Law Society is the most effective professional society in the country, and it is well that those who are about to enter the profession should bear in mind how largely the Society will enter into their professional life and what services the Society renders to the profession.

I have spoken hitherto entirely of the work and surroundings of a solicitor outside his office. I will now say something about his work inside his office. I remember an expression of Macaulay, which has always remained with me since I first thought of becoming a solicitor. In speaking of some political character (I forget whom), Macaulay said, " His aftairs were as multifarious as those of in attorney." How multifarious the affairs of a solicitor are may be realized by the following list of the branches of everyday practice for which provision has to be made in his office, and on which he may be called on at any moment to advise :-

Conveyancing.

Common Law.

Equity.

Bankruptcy.

Company Law.
Probate.

Divorce.

Admiralty.

Criminal Law.

To these during the last six years must be added the emergency legislation arising out of the war and the Defence of the Realm regulations, and at all times must be added the general advice which is coustantly being ralled for from a solicitor on domestic and private matters, involving often questions of morals as much as questions of law. When it is remembered what volumes have been written on each of the branches of law enumerated above, and what varieties of questions may arise in each, and that a solicitor must be not only a lawyer but a man of business, it will be realized how well justified was Macaulay in calling our business "multifarious."

Solicitors as lawyers are at this disadvantage as compared with the Bar, that they do not, as a rule, specialize. I say "as a rule," because there is now a certain amount of specialization, and it has increased of recent years. There are firms of solicitors who have gained a reputation as patent lawyers; others as experts in commercial law with its various sub-divisions-shipping, insurance, stock-exchange business, Parliamentary work, 
etc.; others in divorce and criminal law, and so on. J3ut this specialization is exceptional, and is practically confined to London and a few other large centres of population. With the Bar, on the other hand, it is exceptional not to specialize. Apart from the broad distinction between the C'ommon Law ]3ar and the Chancery Bar, between whirh a man makes his choire at the beginning of his career, there are numerous sub-divisions in ear.h of these branches of business in which specialization is the rule and not the exreption. At the Bar the men who hest surceed are those who by chance or hy choice have specialized in one of the various hranches, such as (ommercial Law, Admiralty, Probate, Divorre, Criminal Lalw and Loral Government work. The specialist in either branch of the profession arcquires a profound knowledge of his sperial subjert and greater conficlence in dealing with it than the general prartitioner. But at the Bar the sperialists form the majority, while with the solicitors the sperialist is the exception. The specialist solicitor is able to do without the assistance of counsel a good deal of the work ronnerted with his special subject for which the general practitionar without any special knowledge would resort to the specialist barrister. For instamee, in the City of London to-day a large number of commercial arbitrations are held, and important questions are derided of which the Bar hears nothing. The parties are usually represented hefore the arbitrators loy their solicitors, who have sperialized in rommerrial law and who are quite "apable of conducting their clients" (ases before arbitrators without counsel. Solicitors hare no right of andience in the High Court, and therefore in rases which go before the court counsel are necessarily engaged. But for every commercial dispute derided in the courts to-day there are probably ten deciled by arbitrator's, and in the majority of these in the ('ity counsel are not employed.

It has been matter of complaint with some solicitors that they have not right of audience in the High Court as they have in the County Courts and other inferine tribunals and before arbitrators. I do not sympathize with the complaint. I do not see how a solicitor's business rould be rarried on if he were liable to be detained personally in Court for a whole day, or for days at a time, in conducting his rases. Arbitrations are quite different. They are fixed at hours ronrenient to the parties after consultation with thom. To surh facilities are possible for ('ourt work. If solicitors had right of andience in the High court, it would ineritally lean to fusim of the two branches of the profession, and this, in my oppinion. would not be for the pullide benefit. 
though, as I have already said, greater unity in the education and training of the whole profession, each branch maintaining its separate functions, but with free right of passage from onc branch to the other, would facilitate the conduct of business and would remove whatever force the agitation in favour of fusion now has behind it. It is obvious that no ordinary man, be he: harrister or solicitor, can be really expert in all the law comprised under the nine heads which I have enumerated above, in the sense of being prepared to advise upon them without preparation at a moment's notice. Such questions may be, and constantly are, sprung upon a solicitor in such circumstances. Probably four out of five of them are easy of solution, such as any welltrained lawyer of either branch can deal with at once without. difficulty. But the fifth may be " "poser," as to which, unless it relates to a question in which the solicitor has had special experience, he is bound in justice to his client and himself to resort to counsel for advice, and the counsel selcuted would, of course, be one who has made a speciality of the subject in question.

Even in matters of practice the solicitor needs the assistance of experts in each branch of the law. Common Law practice, Chancery practice, Probate practice, Divorce practice, Admiraliy practice, Bankruptcy practice, all differ in various details, and the solicitor in large and raried practice provides himself with a staff of whom the heads are specially experienced in the practice of one or more of the different branches of business. If any of my audience should hereafter as an articled clerk enter the office of a firm of solicitors with considerable practice he will probably find it organized into different departments, each presided over by a managing clerk (usually an unadmitted man) with one or two or more assistants under him. A common organization of such an office would be to have

(1) A Common Law department.

(2) A Chancery department.

(3) A Convevancing department.

(4) A C'ashier's and book-keeping department.

(5) A Costs department.

(6) A Copying and Clerical department.

The organization would, of rourse, vary largely with the particular practice of the firm. For instance, a firm with a large Admiralty practice would have a special department for that work. Work which does not fall under any of the heads designated by the titles of the departments and which is not extensive enough to require a department by itself would be assigned to 
one or other of the other departments according to circumstances. Admiralty and divorce and bankruptcy work would generally go to the Common Law department, probate work and the administration of estates to the Chancery department, and the preparation of agreements and such documents to the Conveyancing department.

You will understand from what $I$ have said how dependent a solicitor is upon the honesty and efficiency of his clerks. Not only the finaneial results of his business, but his peace of mind and his reputation are largely in the hands of his clerks. Without efficient and honest clerks his business could not be carried on. The work which a solicitor can do himself would usually not pay the rent of his office, much less provide for the maintenance of himself and his family. I should like to say a few words about this class of men, who thus bulk so large in a solicitor's life. Solicitor's' clerks are a hard-working and capable set of men, doing in the higher grades responsible and lighly important work for a remuneration which is certainly not excessive. Dickens was in early life a solicitor's clerk, but I gather that he never reached a high grade in the profession. Whether he was unfortunate enough to come across the prototype of " the young man of the name of Guppy," I do not know. All I can say is that in the course of my professional life I have known many hundreds of solicitors' clerks, and I have not, I am glad to say, come across one whose character in the slightest degree resembled Guppy's or justifies the representation of that individual as a type of his class.

Let me sketch a typical day's work of a managing clerk in a considerable solicitor's office. Reaching the office, say, at 9.30 , he has to see each of his principals for whom he has cases or work in hand, receive their directions on such cases or work, and see the letters arriving by the morning post relating to them. Then he has to go up to Judge's Chambers to attend summonses on interlocutory applications relating to his case; then he may have to attend a taxation of costs. This probably occupies him till lunch time. After lunch he returns to the office and probably has to see witnesses in some pending case and take their "proofs"; that is, the statements of the evidence which they are prepared to give. This is very important work, for many a case has been lost through the proofs of the witnesses placed in counsel's hands when the case comes to trial being an inaccurate representation of what the witness is prepared to swear to. Nothing is more damning to a case than for counsel to get an arswer from his witness obviously difierent from what the wit- 
ness was expected to say. The taking of proofs may, therefore, last an hour or two, even with the assistance of a shorthand writer. After that is clone the clerk has to write his letters for the day, a work probably of another hour or two, and then, lastly and most important of all, he has to enter in his diary a complete record of all that he has done during the day; for it is from such a record that the professional charges of his firm are made up.

This is a typiral day's work, but, of course, it may be varied indefinitely. For instance, if a case is on for trial and the case is not one demanding the presence of a principal, the managing clerk in charge of it or one of his assistants nust be in Court while the case is proceeding and be ready to produce the paper: required and to give counsel instructions on any point which may arise. In that case the rlerk's office work for the day must be squeezed into the short time between 9.30 and 10.15 in the morning and between 4.15 and 6 or 7 or 8 o'clock in the evening. If this lasts for several days continuously, the strain upon the clerk is considerable and truing.

The naster, of course, is responsible to the client for the efficiency of the clerk's work. The master's work very largely consists in seeing the clients and taking their instructions and supervising and directing his clerk's work to give effect to those instructions. Though the clerk does not initiate, he is the instrument by which the work is done, and the success of the business very largely depends upon the efficiency of the managing clerks in the performance of their duties.

The clerks are usually drawn from the lower middle class. They enter the office as boys in a humble capacity, and they gradually rise according to the ability, zeal and discretion which they display. Sometimes, in cases of special ability, they get their articles given to them by their master-that is, the master pays the stamp of $£ 80$ on the articles-and thus they become solicitors. These cases are not common, and the cases in which marked surcess follows the change of ocrupation are very uncommon. I know of one crise in which I anticipate considerable success on the part of a clerk who has had his articles given to him, and another rave in which considerable success has been attained. But as a rule I think relerks are happier if they remain in their own surroundings and rlass, and that is, of course, the fate of the large majority of them.

The clerks have done much of late years to improve their own education and mental equipment. They have formed a Managing C'lerks' Association for mutual improvement and for 
the protection of the interests of their rlass. This assoriation holds mectings three or four times a year at which they gret a Judge, or someone else eminent in the protescion, to presille, and at which a paper on a legal question is read by some expert. They also have benefit societies to ascist their necessitous members. Latterly, since the war, they huve formed a Law ('lerks' Union, by means of which a sort of Whitley ('omm.il has been formed in London of representatives of the union and of the ('ouncil of the Law Society to disenss questions of wages and the ex:onomic changes brought about by the war. Similar councile have been formed at provincial centres.

As a class solicitors' clerks have suffered heavily as the result of the changed economic ronditions brought about by the war. 'The pre-war' salary of a managing rlerk whose duties $I$ have described ranged from $₫ 200$ to $\$ 400$ a rear, and the salaries of the subordinate clerks ranged downwards to the copying clerk, who received ahout $30 \mathrm{~s}$. or $£ 2$ a week. Inder existing conlitions these are not living wages for men who have to wear black coats and keep up certain appearances. I am glad to think that solicitors as a general rule recognized this before the form:tion of the Clerks' Tnion and raised the salaries of their clerks by an average of, I should estimate, 60 or $i 0$ per cent. The gharges which solicitor's are authorized by law to make against their elients have been increased since the war hy $33: 3 \frac{1}{3}$ per cent. Therefore, in raising the salaries of their alerks to the extent mentioned, they cannot be said to have arted ungenerously. In rases of solicitors in considerable practice this, I believe, has hen generally and gladly done. But a diffienlty has been causerl by the fart that a great number of solicitors are themselves struggling men, earning a very modest inome, and harl hit by the rise in the cost of all the neressaries of life. For these men it may well he impossible to give their clerks a greater rise upon their pre-war salaries than in proportion to the anthorized increase in their own eharges. That is a natter which is now under discussion by the joint commcils above referred to, and as I am a member of the London ('ouncil I can say no more about it except that every member of that rouncil representing the employers is antuated by the kindliest feeling towards the clerks and a desire to do everything that is possible to ease for them the arknowledged difficulties of the situation. The miners struck work recently because they had only obtained a rise of 1:5i) per rent. on their pre-war wages, whereas they claimed, I think, 161 per cent. Solicitors have to be content with $33 \frac{1}{3}$ per rent., and I hope it will he possible to give their clerks generally 
not less than the 60 or $i 0$ per cent. which a large number of them are alrealy receiving, so far as this can be done without injustice to the needier members of the profession. The joint councils, however, are only councils of conciliation. They have no compulsory powers. But in a professional body much can be dome by persuasion, and $I$ have little doubt that the profession as a body will follow as far as possible any recommendation which the councils may make.

Solicitors are officers of the Court, and there are two results of that status on which something should be said. The first is that, as officer's of the ('ourt, they are suhjert to the summary jurisdiction of the court. The second is that their professional rhirges are regulated and rontrolled by Rules of Court except as regards conveyanring and non-litigious matters, in which they are regulated by a rommittee of Judges and solicitors set 11) by statute.

The disciplinary power of the Court has not in theory been interfered with by the Act of 1919 already referred to, by which the Discipline Committee of the Law Society has power to deal with and adjudirate upon all complaints against solicitors. But in practice $I$ anticipate that the powers of the Court will in future be seldom used. In theory a Judge to whom any conduct of a solicitor appears to require explanation has power to take diseiplinary action himself, but in practice the Judge in such rircumstances, since the Act of 1888 was passed, has sent the papers in such cases to the Law Soriety for investigation. That course is obviously fairer to the solicitor than that the Judge should himself exercise his disciplinary powers. He has perhaps formed his opinion on insufficient information and without having had time to consider the circumstances attending the ronduct complained of. An amusing instance of the liability to error in opinions formed hastily upon the Bench occurred the other day. An eminent Judge in the Divorce Court animadverted severely upon a letter written by the solicitor of one of the parties in a case being tried before him. He called upon the solicitor to explain his conduct in writing the letter. The folicitor went into the box and justified himself by producing the draft of the letter settled by counsel who had afterwards been raised to the Bench and, as a Judge, had been a predecessor of the learned Judge who was trying the case. If the solicitor had written the sume letter without the adrice of counsel who afterwards became a Julge it would have gone hard with him, ciwing to the wrong riew which the trial Julge took of the letter. It is fair to assume that the letter was a perfectly proper 
one. The Judge's criticism was silenced at once when he learned that his predecessor on the Bench had drafted the letter, and, but for that circumstance, the solicitor night have had the annoyance and humiliation either of unfavourable comment from the Bench on his conduct or possibly of having to defend himself on a complaint sent by the Judge to the Law Society. The case shows the importance of calm consideration of surch complaints by a body entirely removed from the prejudices and emotions engendered in the litigation out of which the complaint arises. The practical transfer of the jurisdiction to deal with such complaints to the Discipline Committee of the Law Society is a great protection to solicitors and a great benefit to the public who have any genuine complaints to prefer.

The other result of the position of solicitors as officers of the Court is that their professional charges are regulated by law. They are the only profession who are prohibited by law from rharging what they like. A barrister or a dortor or an engineer, or an expert of any kind, except a solicitor, can charge what fees he pleases. The remedy of the client is to go elsewhere if he thinks the fees excessive. Not so with solicitors. The client can always have his solicitor's bill taxed, and the taxation is regulated by an authorized scale of charges which will be applied by the Taxing Master with the same strictness whether the solicitor concerned is the most experienced man in the profession or is a youngster admitted yesterday. The siale by which the costs of litigation are regulated is an antiquated one, and bears but little relation to the actualities of to-day. Probably one of my hearers has had from time to time the misfortune of having a solicitor's detailed bill of costs presented to him. If so, I will undertake to say that he has not read it, or if he has tried to read it he has not understood it. I have been credibly informed, and $I$ believe, that the only part of such a document which interests the ordinary client is the total.

As illustrative of the absurdity of the charges which a solicitor must make against his client may be instanced the authorized charge which, in matters of litigation, the solicitor may make for an attendance on his client. This is $6 \mathrm{~s}$. $8 \mathrm{~d}$., a time-honoured charge once represented by a coin of the realm. This wharge covers any advice which may be given in an interview of, say, half-an-hour's duration. The same amount is the authorized charge for the attendance of the office boy at counsel's chambers to deliver the brief. That is to say, the lan, arcording to the anthorized scale, values the advice which a solicitor may give his client, and which may be the result of a lifetime's experience 
and training, at exactly the same sun as the serrice of a boymossenger for probably less time. The client may, and sometimes does, object. He says, "Why should I pay you 6s. 8ı!. for sending your office hoy, earning a salary of 12 s, a week, to counsel with my papers?" The only answer which a solicitor lats is, "Because the law allows me to make su'h a charge as compensation for the wholly inadequate charge of 6s. 8d. which I am allowed to make to you for taking up half-an-hour of $\mathrm{my}$ personal time, and for advice which may be worth thousands of pounds to you," Legally the answer is perfect. The charge is justified, and would be allowed on taxition. But it is rery irritating to the client and very humiliating to the solicitor. For that reason the practice has sprung up of late sears of solicitors not rendering their bills in detail, but rendering a summarized bill giving the total charges only and the total disbursements. As I have said, the total is the ouly part of the bill which does interest, or ought to interest, the client, and the only part which he would understand.

If a man has confidence in his solicitor he can trust him to iharge only a fair sum, just as he trusts his dortor, who never renders a detailed bill. If the client cannot trust his solicitor to that extent he ought not to employ him. Yet, until recently, the rendering of a bill in lump-sum form was wholly unauthorized and legally ineffectual. A solicitor could not have sued on such a bill, and, even if the client had paid it, he could afterwards call on the solicitor to render a detailed hill and have it taxed. This was a state of things against whir.h the Law Society has protested for years, and quite recently an order las been made under the Solicitors Remuneration Act authorizing solicitors to render lump-sum bills, subjert to the client's right to require details and taxation within a vear and before payment. The difficulty is therefore, on the surfare, remoredbut only on the surface, because the ridiculous system remains of preventing solicitors from charging adequate fees for the work they really do and, in compensation, allowing them to rharge for work which they do not do. This is the way in which the lump sums shown in the bills which will now he universally rendered in that form are made up-a preposterous system which has only survived because laymen have not understood it.

It will be understood from what I hate said that the preparation of a solicitor's bill of costs is a work of considerable intricary and skill. C'lerks have to be kept for the purpose who must hare a thorough knowledge of the scale and be able to insert the charges which, though representing no real work, are 
yet authorized, and to omit or modify charges which, though representing actual work and experience of substantial value, are not anthorized by the scale or are authorized only to an amount whirh, taken by itself, is quite inadequate. Hence you will notice that, in the office organization sketched above, I have included a "Costs Dejartment." In an office of any size ther" must be three or four clerks engaged in nothing hut making out bills of costs--wholly unproductive work which would be unnecessary under any reasonable system of professional remuneration.

This is one of the blemishes in the picture which I promised at the outset that $I$ would not conceal.

But, after all, these things which $I$ have been talking to you about-the Law Soriety, clerks, costs, and in on are the mere tringe of a solicitor's professional life. The essence of it-the real thing which makes bis professional life worth living-is his relations with his ctients. So doubt a solicitor sometimes has to bear in mind St. Paul's behest "to suffer fools gladly," but that is exceptional. A man, it has been said, must have at least two friends, his doctor and his solicitor. The one adninisters to his lodily health and the other to his mental romfort. It is a very pleasunt thing to be told by a client after a quarter of an hour's talk that his mind has been greatly relieved by what one has said, and that he goes away a far happier man than he rame. One rannot always administer that balm. Sometimes, on the contrary, what one must say is the reverse of comforting. Still, the lalm-giving interviews fir exceed those of an opposite rharacter. Most of the mental troubles which afflict mankind are the products of their own fancies or exiggerated apprehensions and can be relieved by the application of a little cool reason. It is a pleasant thing, too, to realize that there are a substantial number of people who rely on one's judgment and turn to one whenever any difficulty arises and who regard one with feelings of confidential friendship. Lord Hannen said, "An honourable solicitor is a family blessing." It might also be said by a commercial man that "an honourable and competent solicitor is a lusiness blessing." A solicitor who, at the end of his career, knows that these things are said and thought of him by a large number of people does not feel that his life has been spent in vain. He may not have made two blades of grass grow where one grew before, but he has brought to many romfort where there was discomfort and hope where there was despair. Therefore I end as I began, by saying that the solicitor's profession, with all its drawbacks, 
difficulties, and temptations, does, when properly conducted, do nothing but good, and it offers adequate scope for the activities of any man of ability and character.

S. Garrett. 